Short- and Long-lived Radionuclide AUG 21997 Particle Size Measurements in a OSTI \title{
Uranium Mine
}

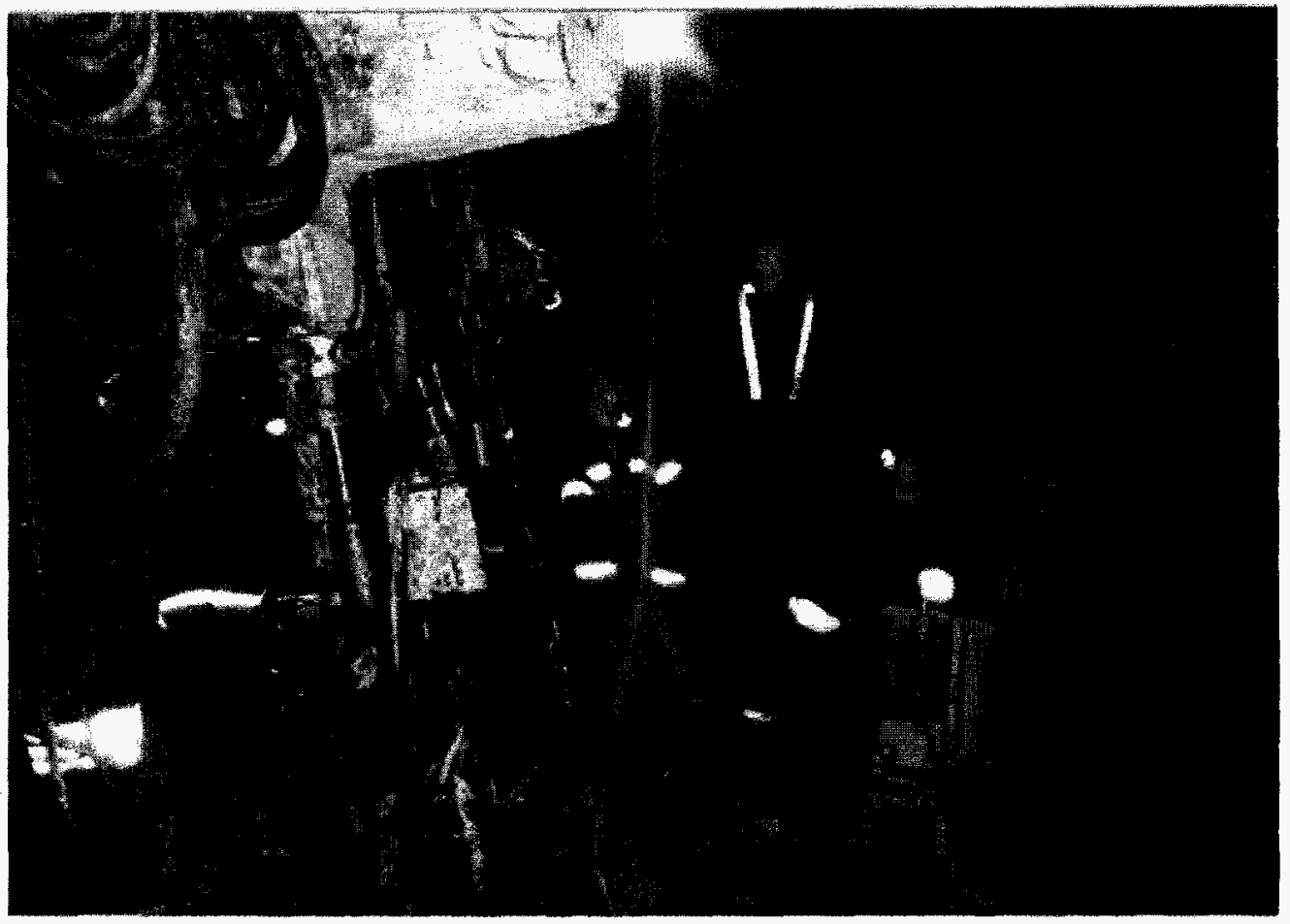

Keng-Wu Tu, Isabel M. Fisenne and Adam R. Hutter 



\section{DISCLAMMER}

Portions of this document may be illegible in electronic image products. Images are produced from the best available original document. 
EML-588

\title{
Short - ANd LONG-LIVEd Radionuclide Particle Size MEASUREMENTS IN A URANIUM MINE
}

\author{
Keng-Wu Tu, Isabel M. Fisenne and Adam R. Hutter
}

Environmental Measurements Laboratory

U.S. Department of Energy

201 Varick Street, 5th Floor

New York, NY 10014-4811

April 1997

\section{DISCLAIMER}

"This report was prepared as an account of work sponsored by an agency of the United States Government. Neither the United States Government nor any agency thereof, nor any of their employees, makes any warranty, express or implied, or assumes any legal liability or responsibility for the accuracy, completeness, or usefulness of any information, apparatus, product, or process disclosed, or represents that its use would not infringe privately owned rights. Reference herein to any specific commercial product, process, or service by trade name, trademark, manufacturer, or otherwise, does not necessarily constitute or imply its endorsement, recommendation, or favoring by the United States Government or any agency thereof. The views and opinions of authors expressed herein do not necessarily state or reflect those of the United States Government or any agency thereof."

This report has been reproduced directly from the best available copy.

Available to DOE and DOE Contractors from the Office of Scientific and Technical Information, P. O. Box 62, Oak Ridge, TN 37831; prices available from (423) 576-8401.

Available to the public from the U.S. Department of Commerce, Technology Administration, National Technical Information Service, 5285 Port Royal Road, Springfield, Virginia 22161, (703) 487-4650. 



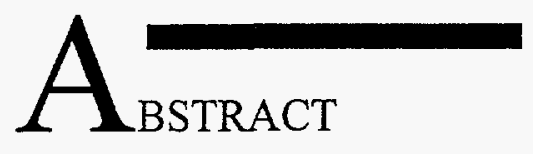

Radon-222 progeny and long-lived radionuclide particle size measurements were conducted in a wet underground uranium mine in Saskatchwan, Canada from November 8-12, 1995. Radon-222 concentrations in the mine varied substantially from $2 \mathrm{kBq} \mathrm{m}^{-3}$ at $90 \mathrm{~m}$ below the surface level to $12 \mathrm{kBq} \mathrm{m}^{-3}$ in the mining areas, $240 \mathrm{~m}$ below the surface level. Radon-222 progeny activity and the potential alpha energy concentration (PAEC) appear to have been affected by the airborne particle number concentration and the size distribution. The particle number concentrations were up to $200 \times 10^{3} \mathrm{~cm}^{-3}$. Only an accumulation mode (30-1000 nm) and some bimodal size distributions in this accumulation size range were significant. The combination of diesel particles and the combustion particles from burning propane gas caused a major modal diameter shift to a smaller size range, 50-85 nm, compared with the previously reported values of around $100-200 \mathrm{~nm}$. The high particle number concentration reduced the unattached progeny $(0.5-2 \mathrm{~nm})$ to $>5 \%$. The nuclei mode $(2-30 \mathrm{~nm})$ in this test was nonexistent, and the coarse mode $(>1000 \mathrm{~nm}$ ), except samples from the drilling areas and on the stopes $(<7 \%$ in coarse modes), was mostly not measurable.

The airborne particle total mass concentrations and long-lived radionuclide alpha activity concentrations were very low, $80-100 \mu \mathrm{g} \mathrm{m}^{-3}$ and $4-5 \mathrm{mBq} \mathrm{m}^{-3}$, respectively, due to high ventilation rates. The mass-weighted size distributions were trimodal, with the major mode at the accumulation size region, which accounts for $45-50 \%$ of the mass. The coarse mode contains the least mass, about $20 \%$. The size spectra inferred from the gross alpha activities were bimodal with the major mode in the coarse size region, $>1000 \mathrm{~nm}$, accounting for more than $70 \%$ of the activity and a minor accumulation mode in the $50-900 \mathrm{~nm}$ size range. These size spectra were very different from those of the ${ }^{222} \mathrm{Rn}$ progeny that predominantly showed a single significant accumulation mode in the $50-85 \mathrm{~nm}$ size region. The accumulation mode in the long-lived radionuclide size spectrum was not found by other investigators in previous measurements in different uranium mines. 



\section{$\mathbf{T}$ ABLE OF CONTENTS}

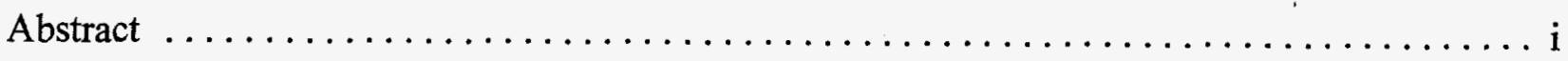

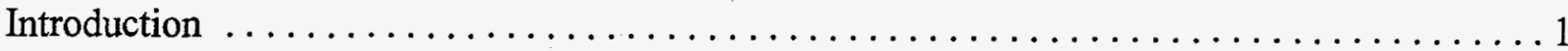

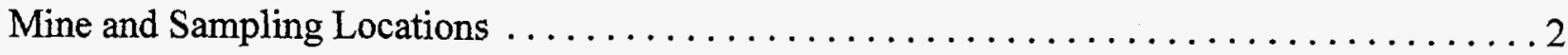

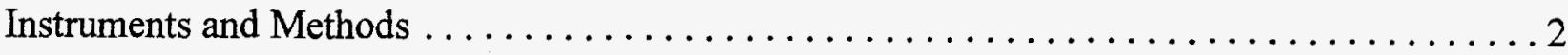

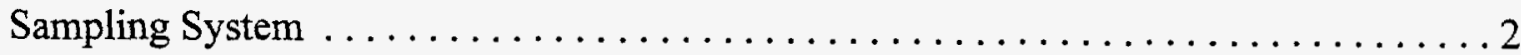

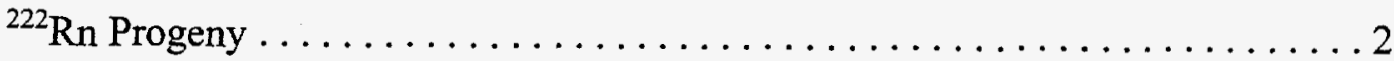



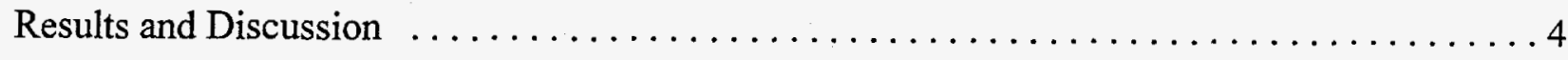

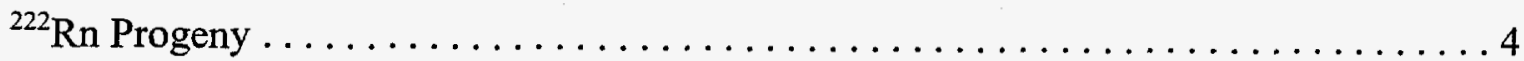

Long-lived Radionuclides $\ldots \ldots \ldots \ldots \ldots \ldots \ldots \ldots \ldots \ldots \ldots \ldots \ldots \ldots \ldots \ldots \ldots$

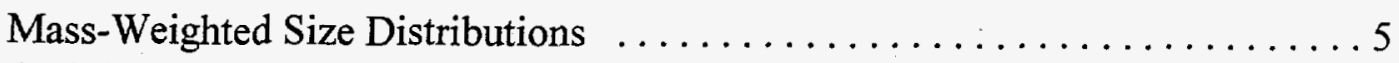

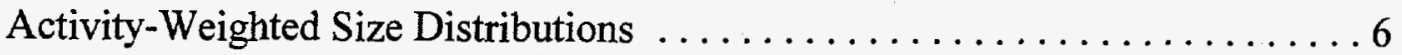

Individual Long-Lived Isotopes $\ldots \ldots \ldots \ldots \ldots \ldots \ldots \ldots \ldots \ldots \ldots \ldots \ldots \ldots \ldots \ldots \ldots$

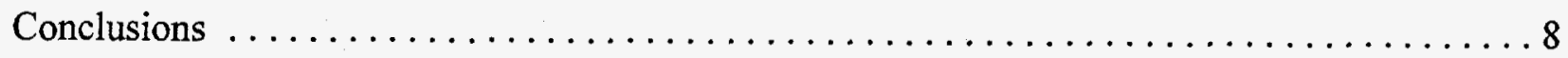

Acknowledgments $\ldots \ldots \ldots \ldots \ldots \ldots \ldots \ldots \ldots \ldots \ldots \ldots \ldots \ldots \ldots \ldots \ldots$

References $\ldots \ldots \ldots \ldots \ldots \ldots \ldots \ldots \ldots \ldots \ldots \ldots \ldots \ldots \ldots \ldots \ldots \ldots \ldots$ 



\section{$\coprod_{\text {NTRODUCTION }}$}

It has been recognized that one of the major health hazards in uranium mining is mainly from the inhalation of short-lived radon progeny and long-lived radionuclides (NCRP 1984; ICRP 1987), which affect the respiratory tract by emitting alpha particles. Measurements of short-lived radon progeny and their associated particle size distributions in uranium mines in the 1960s and 1970s have been described (USAEC 1960; Palmer et al. 1964; Dahl et al. 1967; George and Hinchliffe 1972; George et al. 1975; Mercer 1975; Bigu and Kirk 1980). Some of the data from these earlier studies were used by the International Commission on Radiological Protection (ICRP) and the National Council on Radiation Protection and Measurements (NCRP) task groups to develop inhalation models for the determination of respiratory tract deposition as a function of particle size. However, the particle size spectra were poorly determined in those earlier studies due to the limitations of the instrumentation used. Consequently, the National Research Council Report (1991) recommended the development of better information on the particle size of uranium mine aerosols.

Solomon et al. (1993) used a diffusion battery system to conduct measurements in the Olympic Dam uranium mines in 1991. This system, like some of those used in the 1970s, covered sizes up to $1000 \mathrm{~nm}$. In May 1994, the Environmental Measurements Laboratory (EML) participated in the International Intercomparison of Measurements of Radon Progeny Particle Size Distributions in the Twilight Mine, a former uranium mine used by the U.S. Department of Interior, Bureau of Mines (USBM) for research. EML used improved particle sizing instrumentation, covering sizes from $0.5 \mathrm{~nm}$ up to $10000 \mathrm{~nm}$, and the results were reported in Knutson and $\mathrm{Tu}$ (1996). The Twilight research mine is a dry mine. Data obtained from that mine may not represent those from wet uranium mines. Thus, measurements from a wet uranium mine are needed for a better understanding of the particle size distributions in this mine environment.

In addition, particle size measurements for radionuclides in uranium mines have thus far focused on short-lived ${ }^{222} \mathrm{Rn}$ progeny. Information on the long-lived progeny is lacking. A few measurements on the long-lived radionuclide particle sizes were conducted in Canada and Australia in the 1980s (Duport and Edwardson 1985; Leach et al. 1982, Brabham 1991). These measurements were performed with cascade impactors, which preclude detection in the small size regions of 30 to $400 \mathrm{~nm}$.

From November 8-12, 1995, EML conducted a study in Cameco Corporation's Eagle Point, an active, wet, uranium mine, in Saskatoon, Saskatchewan, Canada. Presented in this report are the results from this study, which include improved ${ }^{222} \mathrm{Rn}$ progeny and long-lived size distributions. Also, discussed are comparisons to previous measurements conducted by other investigators in different uranium mines. 


\section{$\mathbb{1}_{\text {ine and Sampling Locations }}$}

Cameco's Rabbit Lake site is about $700 \mathrm{~km}$ north of Saskatoon, Saskatchewan in the Athabasca basin region. Measurements were carried out from November 8-12, 1995 in the Eagle Point underground uranium mine, which is a wet mine. The relative humidity in the mine during the sampling week was always $>95 \%$. The temperature inside the mine is maintained at $\sim 5^{\circ} \mathrm{C}$ by direct burning of propane gas to heat the ventilation air. Currently, the deepest mining area is $270 \mathrm{~m}$ below the surface. Blasting takes place during shift changes each evening. The mine operates continuously with two, $12 \mathrm{~h}$ shifts daily. Underground ore-carriers, loaders and most operating equipment are diesel-powered, with only a small amount of electric-powered equipment.

The original plan was to sample at three different locations. The first sampling site was chosen at an area $120 \mathrm{~m}$ below the surface level. Unfortunately, during the first sampling period dripping and standing water electrically shorted out some of our instruments. Therefore, the equipment was moved to a bolt-storage bay, $90 \mathrm{~m}$ below the surface, a relatively dry area but somewhat distant from mining activities. However, this site enabled sampling from a major mine exhaust, providing a good opportunity to estimate the "average" mine atmosphere. Nine out of the 17 successful samples were taken in this area.

To take samples near the active mining areas, the sampling equipment was moved onto underground trucks. Samples were taken as close to mining activities as possible, and were then rushed back to the bolt-storage area for counting. The delay time between the end of sampling and the start of counting ranged from 5-10 min. In these cases, substantial ${ }^{218}$ Po decay occurred before counting was started.

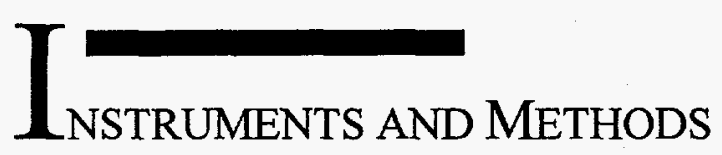

\section{SAMPLING SYSTEM}

\section{Rn Progeny}

The sampling set up and the procedures used in this mine were similar to those used in the Twilight mine in Colorado in 1994 (Knutson and Tu 1996). Briefly, a micro-orifice uniform deposit impactor (MOUDI; MSP Corp., Minneapolis, MN) was used with a graded screen array (GSA; Holub and Knutson 1978) to cover the expanded size range of $0.5-15000 \mathrm{~nm}$. The quality assurance steps for the sampling system and analysis process are described in the EML Procedures Manual, Section 2 (HASL-300 1997).

The GSA consists of 60 -and 100 -mesh stainless steel screens with a $40 \mathrm{~mm}$ effective flow diameter. These screens were stacked into a $66 \mathrm{~mm}$ diameter single holder in the abovementioned order with the 60 -mesh screen upstream. Ten impaction stages and the corresponding 
cut-off diameters for the MOUDI are listed in Table 1. The EML MOUDI can only operate with eight stages, and a back-up filter. In this study, stages 1 to 5 and stages $8, \mathrm{~B}$, and BB were used to cover sizes up to $15000 \mathrm{~nm}$. The samples were taken simultaneously using the MOUDI, the GSA and an open-faced filter. Sampling flow rates were $30 \mathrm{~L} \mathrm{~min}^{-1}$ for the MOUDI, and $11 \mathrm{~L}$ $\min ^{-1}$ for the GSA and an open-faced filter. After sampling, the front of each screen, the impaction plates, and the reference filter were simultaneously individually alpha-counted using 12 scintillation alpha-counters. The ${ }^{222} \mathrm{Rn}$ progeny activities were calculated using the RaabeWrenn least-squares method (Raabe and Wrenn 1969). A computer program based on an expectation-maximization algorithm (EM; Maher and Laird 1985), developed by Knutson (1991), was used to calculate particle size distributions from the activities measured on each impaction plate of the MOUDI and on the screens. The ${ }^{222} \mathrm{Rn}$ concentrations during sampling were obtained from grab samples (Hutter 1995). The aerosol particle number concentration was measured with a Gardner particle counter (Gardner Associates, Inc., Schenectady, NY), and an electrical aerosol size analyzer (EAA, TSI, Inc., model 3030, Minneapolis, MN) was employed to measure the number-weighted particle size distributions. Because of fluctuating particle number concentrations caused by the diesel particles produced by edpisodic mining activities, the data from the EAA measurements in a continuous mode were found to be unreliable. The EAA was then operated manually.

\section{Long-lived Radionuclides}

The MOUDI was also used for sampling long-lived radionuclide particles. During the day shift, the MOUDI was used for ${ }^{222} \mathrm{Rn}$ progeny size measurements by sampling for $5-10 \mathrm{~min}$, and then immediately counting each of the impaction plate samples. For long-lived radionuclides size measurements, the MOUDI sampled continuously at $30 \mathrm{~L} \mathrm{~min}^{-1}$ for $15 \mathrm{~h}$ over night. Analyses for long-lived radionuclides were performed after returning to EML.

To prevent particle bounce from the impaction plates, the aluminum foil substrates were prepared in advance by uniformly coating them with a thin layer of silicon grease, $0.3-0.4 \mathrm{mg}$ $\mathrm{cm}^{-2}$ (Cling-Surface Co., Inc., Angola, NY). Each coated substrate was weighed 1 week after coating. They were then positioned on the impaction plates with clamp rings. After the impactor was assembled with the impaction plates, it was then rotated during sampling to obtain a nearly uniform particle deposit on the impaction plates (Marple et al. 1991).

After sampling, the substrates with the samples were again reweighed and were also alphacounted using two different methods.

EML total alpha measurement system: Total alpha measurements of both the MOUDI stages and back-up filters were performed by scintillation counting. The EML alpha scintillation system consists of a $5 \mathrm{~cm}$ diameter photomultiplier tube (PMT) with $\mathrm{ZnS}(\mathrm{Ag}$ ) powder applied to the face. A sample is placed in a $5 \mathrm{~cm}$ diameter depression in a drawer. There is a $3 \mathrm{~mm}$ air gap between the sample and the scintillator. The detection system is calibrated using a standardized source of an alpha emitter electrodeposited on a metal disc. The mean and standard error of 62 measurements with the standard source yielded a detection efficiency of $34 \pm 0.1 \%$. 
Background measurements were performed with coated blank (unused) aluminum foils and glass fiber filters from the same box as that used in the impactor sample collections. The mean and standard error of two aluminum stage background measurements was $0.11 \pm 0.01$ counts $\mathrm{min}^{-1}$. The mean and standard error of six glass filter measurements was $0.43 \pm 0.03$ counts $\mathrm{min}^{-1}$.

All the impactor samples were measured for a sufficient time to collect 1000 counts. The measurement periods averaged $4300 \mathrm{~min}$, ranging from 1800 to $8600 \mathrm{~min}$. The lower limit of detection (LLD) at the $95 \%$ confidence level for the impactor stages and the back-up filters was calculated using the method of Pasternack and Harley (1971). Based on the backgrounds, counting efficiency, and average measurement time given above, the LLD value for the impactor stages was $0.35 \mathrm{mBq}(0.02 \mathrm{dpm})$ and $1 \mathrm{mBq}(0.06 \mathrm{dpm})$ for the back-up filters.

Victoreen continuous air monitor (Alpha CAM): The alpha CAM (Victoreen Inc., Cleveland, $\mathrm{OH}$ ), which uses a solid-state silicon detector with a $1700 \mathrm{~mm}^{2}$ sensitive area, was also used to count the impactor samples and backup filter. The alpha CAM is based on microprocessor technology with a PROM memory. The monitor was calibrated with three standard sources, ${ }^{239} \mathrm{Pu},{ }^{238} \mathrm{U}$ and ${ }^{241} \mathrm{Am}$. The alpha counting efficiency of the device was determined to be $37 \%$. The samples from each stage and the backup filter (Reeve Angel glass fiber filter, grade 934AH) were each measured for $8 \mathrm{~h}$. The average background counts from the two coated aluminum foil and four glass fibers were $0.11 \pm 0.02$ and $0.44 \pm 0.04$ count $\mathrm{min}^{-1}$, respectively.

The calculated activities were then used to determine particle size distributions using the same procedures as those for the ${ }^{222} \mathrm{Rn}$ progeny size determination.

\section{$\mathcal{R}_{\text {esults and Discussion }}$}

\section{${ }^{222}$ RN PROGENY}

Table 2 shows the results from 17 successful samples out of 18 (one was lost due to an electrical shut down) collected at five different sampling sites within the mine. The measurement suite included aerosol particle and ${ }^{222} \mathrm{Rn}$ concentrations, the calculated ${ }^{218} \mathrm{Po}$ activities, potential alpha energy concentrations (PAEC), activity weighted geometric mean diameters (AGMD) for the unattached nuclei, accumulation and coarse modes and the fractions of activity in each mode. The number in the first column shows the identification number (first or first 2 digits), the collection hour (last two digits) and the collection day of the month (middle two digits). The activity weighted size distributions for ${ }^{218} \mathrm{Po},{ }^{214} \mathrm{~Pb},{ }^{214} \mathrm{Bi}$ and the PAEC are shown in Figures 1 to 3. The legends on the upper left corner in each figure represents the kind of sample and sampling date and time, e.g., 1 . RO815 in Figure 1 means number $1{ }^{222} \mathrm{Rn}$ progeny sample taken at $15: 00 \mathrm{~h}$ on day 8 .

Aerosol concentrations in the mine varied from $55 \times 10^{3}$ to $200 \times 10^{3} \mathrm{~cm}^{-3}$, depending on the sampling sites and sampling times. High concentrations around $200 \times 10^{3} \mathrm{~cm}^{-3}$ were associated with busy mining activities, such as heavy traffic, huge diesel powered ore trucks passing by or 
operation of mining machines. An additional source of particles was from the combustion of propane gas used for heating the working areas. This was shown in the dark black color of the filters and from the measurements with the EAA. The data from the EAA shows that the number-weighted particle size distribution was broad, $10-700 \mathrm{~nm}$, with a small but sharp peak in the $20-30 \mathrm{~nm}$ region. This suggests that the particles from combustion of propane gas were the dominant aerosol in the mine air. The ${ }^{222} \mathrm{Rn}$ concentration varied by up to a factor of 6 between sampling areas. It ranged from $2100 \mathrm{~Bq} \mathrm{~m}^{-3}$ at the bolt storage area (far from the mining area) to $12000 \mathrm{~Bq} \mathrm{~m}^{-3}$ near exposed ore (Table 2). Because of high aerosol concentrations, the unattached fractions were generally $>5 \%$, except samples for $6,7,12$ and 14 . Among these four samples, only those in sample 14 may be the real unattached mode. The other three samples were most likely formed by the attachment of progeny on ultra-fine particles $<10 \mathrm{~nm}$. Since

${ }^{214} \mathrm{~Pb}$ and ${ }^{214} \mathrm{Bi}$ concentrations in most of the samples are very low (many have insignificant values), the unattached modes shown in samples 5 (Figure 1), 7, 9,11 and 12 (Figure 2) and 13 and 17 (Figure 3) are considered artifacts created during the size unfolding process caused by the poor statistics.

As expected, a well-defined single mode or bimodal size distributions in the accumulation size range, which contain a large fraction of activity, 70 to $100 \%$, appear in all samples (Table 2 and Figures 1 to 3 ). The activity geometric mean diameter (AGMD) ranged from $50-85 \mathrm{~nm}$, corresponding to the peaks in the $57 \mathrm{~nm}$ to $90 \mathrm{~nm}$ size range. These values are smaller than those obtained in the Twilight mine (AGMD in the range of $83-93 \mathrm{~nm}$ and peaks at $>100 \mathrm{~nm}$; Knutson and Tu 1996), and in the Olympic Dam mine (AGMD 200-300 nm; Solomon 1991). Based on the tracheobronchial (TB) deposition model developed by Rudolf et al. (1990), ${ }^{222} \mathrm{Rn}$ progeny AGMD in the 50-85 nm range obtained in the Rabbit Lake mine will result in higher TB deposition than those from AGMD at 200-300 nm used by the ICRP (1981). The coarse modes observed for samples 8 and 13 (Figures 2 and 3) may be artifacts due to poor statistics.

\section{LONG-LIVED RADIONUCLIDES}

Four long-term MOUDI collections were made for long-lived radionuclide sizes, but only two of them were successful. The failures were caused by substrates that were blown-off during sampling. These blown-off substrates partially blocked the air flow, and disturbed the sampling conditions. Therefore, these two samples were discarded because of their questionable reliability. The results from the two successful samples are presented in Table 3 and Figures 4 and 5.

Table 3 shows the impaction stages used in this mine sampling, the corresponding cut-off particle diameters, the alpha activities collected on each stage (measured with two different alpha counters), and the particle mass load on each stage determined with an A and D analytical balance (Model FR200II).

\section{Mass-Weighted Size Distributions}

As shown in the last two columns of Table 3 and in Figures 4 (ms10) and 5 (ms12), both mass-weighted size distributions from these two samples consist of three clearly separated well- 
defined modes (trimodal size spectra with nuclei, accumulation, and coarse modes). The fractions of particles in each mode are $26-29 \%, 44-53 \%$ and around $20 \%$, respectively. These mass-weighted size spectra are different from those measured by Brabham (1991) and Duport and Edwardson (1985) in which only two modes were defined, accumulation and coarse, where identified, with more than $80 \%$ of the particles in the coarse mode. The nuclei mode, $<40 \mathrm{~nm}$, observed in the present samples but not in the studies by Brabham and Duport and Edwardson, was likely formed from the combustion of propane gas. The accumulation mode, $50-1000 \mathrm{~nm}$, most probably results from the diesel-powered trucks and mining machines. The coarse mode, $>1000 \mathrm{~nm}$, was evidently produced from the mechanical process of ripping and loading material from the main ore. The total particle mass concentration in this Rabbit Lake mine was 93-110 $\mu \mathrm{g} \mathrm{m}^{-3}$.

\section{Activity-Weighted Size Distributions}

Alpha activities on each stage measured with two different detectors agree reasonably well (Table 3 and Figures 4 and 5). The total alpha activity concentrations measured for this mine

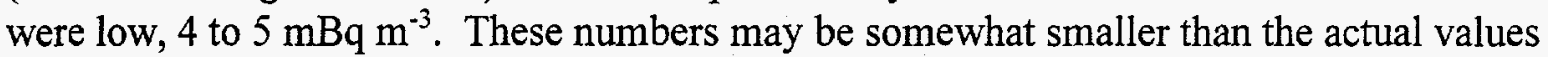
because the subtrates collecting the samples were coated with a thin layer of silicon oil and so some of the alpha particles that were emitted from the samples might not have been detected. Therefore, chemical analyses for the individual isotopes will be performed to resolve this issue.

The activity-weighted size distributions shown in Figures 4 and 5 were unfolded using total alpha activity on each stage and the back-up filter. The particle size distributions for individual isotopes, such as ${ }^{238} \mathrm{U},{ }^{226} \mathrm{Ra},{ }^{210} \mathrm{Po}$ and ${ }^{232} \mathrm{Th}$ were only qualitatively analyzed because the alpha counts for individual decay products were considered insufficient for a reliable size analysis.

Unlike mass-weighted size distributions, which are weighted heavily in the nuclei and accumulation modes (Table 3 and Figures 4 and 5), the activity-weighted size distributions consist of more than $70 \%$ of the alpha activity in the coarse modes (AGMD $4000-5000 \mathrm{~nm}$ ) and $>30 \%$ in the accumulation modes (Figures 4 and 5: curves S310v, S310i, S412v and S412i). This suggests that these coarse mode particles were very likely mechanically produced from the mining activities on the ore. These coarse modes were also found in the Elliot Lake uranium mines, Canada (Duport and Edwardson 1985) and in the Olympic Dam uranium mines in Australia (Brabham 1991). According to the Rudolf et al. (1990) TB deposition model, the TB deposition resulting from these coarse mode particle AGMDs of 4000-5000 nm may be higher than those from the AGMD at $1000 \mathrm{~nm}$ assumed by the ICRP (1979).

The small particles in the accumulation modes (Figures 4 and 5) were not found in the measurements of Duport and Edwardson (1985) and Brabham (1991). These particles are not likely produced from the attachment of pure long-lived radionuclides onto aerosol particles in the mine air. If attachment to the mine aerosol particles was the dominant mechanism, the AGMDs should be at around $50-85 \mathrm{~nm}$ as shown in the ${ }^{222} \mathrm{Rn}$ progeny size spectra (Table 2 and Figures 13 ). Instead the AGMDs for those long-lived radionuclides aerosol particles in the accumulation modes are 112 to $245 \mathrm{~nm}$. One possible explanation is that those particles were originally large particles, $>1000 \mathrm{~nm}$, produced mechanically from the mining process and these coarse particles were in some form of chemical compound, such as ammonium diuranate that is partially soluble 
in water in the mine, resulting in smaller sizes. Some of these particles may have even been completely dissolved, became droplets, and these droplets may have undergone physical processes that resulted in yet smaller sizes.

It is unlikely that the small particles were re-entrained particles that bounced off the upper stages and were then re-captured on the lower stages, because as mentioned before, all the substrates used in our sampling were coated with a thin layer of silicon grease to prevent particle bounce from the upper stages, and the mass load on each upper six stages was very low, 15-80 $\mu \mathrm{g} \mathrm{cm}{ }^{-2}$.

Monte Carlo error analyses (Knutson 1991) show that, for mass-weighted size distributions, the larger uncertainties are in the nuclei and coarse modes. This may be because the nuclei mode was calculated based on the samples collected on the backup filter and the particle loss as a function of particle size. The greater uncertainty in the coarse mode is mainly due to low mass loading on the upper five stages. Contrary to the mass-weighted size distributions, the greater uncertainty in the activity-weighted size distribution is in the accumulation mode in which the alpha activities are relatively low.

The alpha activities detected with the alpha scintillation monitors need to be compared with those obtained from chemical analyses to resolve the issue of undetected alphas lodged in the silicon grease that coats the impaction substrates used for sampling of long-lived radionuclides. In this test, we were unable to sample $>15 \mathrm{~h}$ for the long-lived radionuclides. Longer sampling times should be taken into consideration for future tests to obtain sufficient activity in the samples that would improve counting statistics and data reliability.

\section{Individual Long-Lived Isotopes}

Qualitative measurements from EML solid-state alpha spectrometry systems suggest that all three of the natural series, uranium, actinium and thorium, are present. A more specific analysis was done with the Victoreen alpha spectrometer. These spectra were analyzed to evaluate the number of counts accumulated within the distinguishable peaks. Due to very low counts for each individual isotope, none of those data were considered to have sufficient accuracy to be used for quantitatively reliable determination of the particle size distributions. However, from these spectra, peaks due to ${ }^{238} \mathrm{U},{ }^{230} \mathrm{Th},{ }^{226} \mathrm{Ra},{ }^{210} \mathrm{Po}$, and ${ }^{232} \mathrm{Th}$ were identified and their qualitatively determined activities were used to derive particle size distributions for each isotope. The results show that, like those obtained from gross alpha activity, all the isotope size distributions mentioned above consist of two modes, accumulation and coarse. However, the activity distributions between these two modes among those isotopes are different. The ratios of activities in the coarse mode to those in the accumulation mode are: 9 to 1 for ${ }^{238} \mathrm{U}$ and ${ }^{232} \mathrm{Th}$; 2 to 1 for ${ }^{230} \mathrm{Th} ; 1$ to 1 for ${ }^{210} \mathrm{Po}$; and 1 to 2 for ${ }^{226} \mathrm{Ra}$. 


\section{ONCLUSIONS}

In the accumulation size region, a single mode or bimodal size distribution was found in all

${ }^{222} \mathrm{Rn}$ progeny particle size spectra. However, no nuclei mode was present. Except for samples collected near mining activities, no significant amount of coarse particles appeared in the samples. This is different from the size distributions obtained from the Twilight mine samples which contained significant coarse mode particles (Knutson and Tu 1996). Because of high aerosol particle number concentrations (up to $200 \times 10^{3} \mathrm{~cm}^{-3}$ ) in the mine air, the unattached ${ }^{222} \mathrm{Rn}$ progeny was reduced to $<5 \%$, while the PAEC was high, up to $8.3 \mu \mathrm{J} \mathrm{m}^{-3}$. The ${ }^{214} \mathrm{~Pb}$ and ${ }^{214} \mathrm{Bi}$ activities were extremely low. Their size distributions have been carefully examined to resolve artifacts produced by unfolding using the EM algorithm. The ${ }^{222} \mathrm{Rn}$ progeny AGMDs at 50 to 85 $\mathrm{nm}$ in this mine may result in higher TB deposition than the ICRP (1981) estimated GMD values of $200-300 \mathrm{~nm}$.

The long-lived radionuclide aerosol particle gross activity and the total mass concentration were very low but quantitatively measurable. All three of the natural series, ${ }^{238} \mathrm{U},{ }^{235} \mathrm{U}$ and ${ }^{232} \mathrm{Th}$, are present in the samples. Mass-weighted size distributions show three modes with more than $70 \%$ of the mass in the accumulation and nuclei modes. However, contrary to the mass weighted size spectra, the total alpha activity-weighted size spectrum is bimodal with more than $70 \%$ of the total activity in the coarse mode. This activity-weighted size distribution is completely different from that of ${ }^{222} \mathrm{Rn}$ progeny, which show that $70-100 \%$ of the activity is in the accumulation size region with very little coarse mode. Individual isotopes of these long-lived radionuclides also show bimodal activity size spectra with the major modes in the coarse size region, except for ${ }^{226} \mathrm{Ra}$, but at different proportions of activity in the coarse mode. The AGMDs at $4000-5000 \mathrm{~nm}$ for the long-lived radionuclides size distributions are much larger than the $1000 \mathrm{~nm}$ diameter quoted by the ICRP (1979).

\section{$A_{\text {cknowledgments }}$}

This Canadian uranium mine study was initiated by Earl $O$. Knutson before his retirement in 1995. The authors are grateful for his valuable information and suggestions in dealing with longlived radionuclides in terms of their alpha counting and particle size distributions. The authors wish to express thanks to the Atomic Energy Control Board of the Canadian government and the Cameco Company for allowing us to use this uranium mine. The assistance from the Cameco management and employees, particularly John Takala, Cliff Lusby, Carl Leia and Paul Fox, is gratefully appreciated. Assistance from EML colleagues is acknowledged as follows: Al Cavallo for his assistance in carrying out the sampling program in the mine, Kevin Clancy for taking care of the instruments transportation, Nancy Chieco for editing, Earl O. Knutson and Ronald Knuth for their comments and suggestions. This study was sponsored by the Office of Health and Environmental Research (OHER), Office of Energy Research, U.S. Department of Energy. 


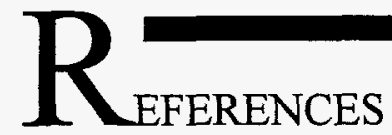

Bigu, J. and B. Kirk

Determination of Unattached ${ }^{222} \mathrm{Rn}$ Daughter Fractions in Some Uranium Mines

Workshop on the Attachment of Daughters, Measurement Techniques

and Related Topics

University of Toronto, Canada, October 30 (1980)

Brabham, N.

Particle Size Distribution of Airborne Dust in the Olympic Dam

Underground Mine

Radiat. Prot. Australia 9:13-19 (1991)

Dahl, A. H., K. J. Schiager, R. J. Reece, and P. W. Jacoe

${ }^{222} \mathrm{Rn}$ Progeny Inhalation Study

Second Annual Report under U. S. Atomic Energy Commission

Contract No. AT(11-1)-1500, Vol. 45 (1967)

Duport, P. J. and E. Edwardson

Determination of the Contribution of Long-lived Dust to the Committed Dose Equivalent

Received by Uranium Mine and Mill Workers in the Elliot Lake Area

Atomic Energy Control Board Report, Info-0167-2, Ottawa, Canada (1985)

EML Procedures Manual

N. A. Chieco (Editor)

HASL-300, 28th Edition, U.S. Department of Energy, New York, NY, Vol. 1 (1997)

George, A. C., L. Hinchcliffe, and R. Sladowski

Size Distributions of ${ }^{222} \mathrm{Rn}$ Daughter Particles in Uranium Mines Atmospheres

Am. Ind. Hyg. Assoc. J. 36:484-490 (1975)

George, A. C. and L. Hinchcliffe

Measurement of Uncombined ${ }^{222} \mathrm{Rn}$ Daughters in Uranium Mines

Health Phys. 23:791-803 (1971)

Holub, R. F. and E. O. Knutson

Measuring Polonium-218 Diffusion-coefficient Spectra Using Multiple Wire Screens

In: ${ }^{222}$ Rn and Its Decay Products: Occurrence, Properties and Health Effects

ACS Symposium Series 331, American Chemical Society, Washington, D.C., pp. 340-356 (1987)

Hutter, A. R.

A Method for Determining Soil Gas ${ }^{220} \mathrm{Rn}$ (Thoron) Concentrations

Health Phys. 68:835-839 (1995) 
International Commission on Radiological Protection

Limits for Intakes of Radionuclides by Workers

ICRP Publication 32, Oxford, Pergamon Press, NY (1979)

International Commission on Radiological Protection

Limits for Inhalation of ${ }^{222} R n$ Daughters by Workers

ICRP Publication 32, Oxford, Pergamon Press, NY (1981)

International Commission on Radiological Protection

Lung Cancer Risk from Indoor Exposures to ${ }^{222} R n$ Daughters

ICRP Publication 50, Oxford, Pergamon Press, NY (1987)

Knutson, E. O.

Application of the Expectation-maximization Algorithm to the Processing of Cascade Impactor Data: The Method of Log Normal Components

J. Aerosol Sci. 22:s267-s270 (1991)

Knutson, E. O. and K. W. Tu

Size Distribution of ${ }^{222} \mathrm{Rn}$ Progeny Aerosol in the Working Area

of a Dry Former Uranium Mine

Environ. Int. 22:617-632 (1996)

Leach, V. A., K. H. Lokan, and L. J. Martin

A Study of Radiation Parameters in an Open-pit Mine

Health Phys. 43:363-375 (1982)

Maher, E. F. and N. M. Laird

EM Algorithm Reconstruction of Particle Size Distributions

from Diffusion Battery Data

J. Aerosol Sci. 16:557-570 (1985)

Marple, V. M., K. L. Rubow, and S. M. Behm

A Microorifice Uniform Deposit Impactor (MOUDI): Description,

Calibration, and Use

Aerosol Sci. Technol.14:434-446 (1991)

Mercer, T. T. and W. A. Stowe

Deposition of Unattached ${ }^{222} \mathrm{Rn}$ Decay Products in an Impactor Stage

Health Phys. 17:119-121 (1969)

National Council on Radiation Protection and Measurements

Evaluation of Occupational and Environmental Exposure to ${ }^{222} \mathrm{Rn}$

and ${ }^{222} \mathrm{Rn}$ Daughters in the United States

NCRP Report No. 78, Bethesda, MD (1984) 
National Research Council

Comparative Dosimetry of ${ }^{222} \mathrm{Rn}$ in Mines and Homes

National Academy Press, Washington, D. C. (1991)

Palmer, H. E., R. W. Perkins, and B. O. Stuart

The Distribution and Deposition of ${ }^{222} \mathrm{Rn}$ Daughters Attached to Dust Particles in the Respiratory System of Humans Exposed to Radium Mine Atmospheres

Health Phys. 10:1129 (1964)

Pasternack, B. S. and N. H. Harley

Detection Limits for Radionuclides in the Analysis of Multicomponent

Gamma Ray Spectrometer Data

Nuclear Inst. Methods. 91:533-540 (1970)

Raabe, O. G. and M. E. Wrenn

Analysis of ${ }^{222} \mathrm{Rn}$ Daughter Samples by Weighted Least Squares

Health Phys. 17:593-605 (1969)

Rudolf, G., R. Kobrich and W. Stahlhofen

Modeling and Algebraic Formulation of Regional Aerosol Deposition in Man

J. Aerosol Science. 21:5403-5406 (1990)

Solomon, S. B., M. Wilks, R. O'Brien and B. Ganakas

Particle Sizing of Airborne Radioactivity Field Measurements at Olympic Dam

Australian Radiation Laboratory Report AR/TR113, ISSN 0157-1400, Yallambie, Victoria, Australia (1993)

U.S. Atomic Energy Commission

Experimental Environmental Study of AEC Leased Uranium Mines

Technical Report HASL-91, Health and Safety Laboratory, New York, NY (1960) 
TABLE 1

IMPACTION STAGES AND THE CORRESPONDING CUT-OFF DIAMETERS FOR THE MOUDI

\begin{tabular}{lc}
\hline Stage & $\begin{array}{c}\text { Cut-off diameter } \\
(\mathrm{nm})\end{array}$ \\
\hline Inlet & 15000 \\
1 & 10000 \\
2 & 5600 \\
3 & 3200 \\
4 & 1800 \\
5 & 1000 \\
6 & 560 \\
7 & 290 \\
8 & 173 \\
B & 97 \\
BB & 45 \\
\hline
\end{tabular}


TABLE 2

RADON PROGENY SIZE DISTRIBUTIONS IN THE RABBIT LAKE URANIUM MINES, SASKATCHEWAN, CANADA, NOVEMBER 1995

\begin{tabular}{|c|c|c|c|c|c|c|c|c|c|c|c|c|}
\hline \multirow[b]{2}{*}{$\begin{array}{l}\text { Test } \\
\mathrm{D}, \mathrm{H}^{*}\end{array}$} & \multirow[b]{2}{*}{$\begin{array}{l}\text { Location \& event } \\
\text { (below surface level) }\end{array}$} & \multirow[b]{2}{*}{$\underset{\left(\mathrm{cm}^{-3}\right)}{\mathrm{CNC}^{* *}}$} & \multirow[b]{2}{*}{$\underset{\left(\mathrm{kBq} \mathrm{m^{-3 }}\right)}{\text { Radon }_{-3}}$} & \multirow{2}{*}{$\begin{array}{c}{ }^{218} \mathrm{Po}^{\dagger} \\
\left(\mathrm{Bq}^{-3}\right) \\
\& \\
\mathrm{PAE}^{-3} \\
\left(\mu \mathrm{J} \mathrm{m}^{-3}\right)\end{array}$} & \multicolumn{2}{|c|}{$\begin{array}{l}\text { Unattached } \\
\text { mode }\end{array}$} & \multicolumn{4}{|c|}{$\begin{array}{l}\text { Accumulation } \\
\text { size range }\end{array}$} & \multicolumn{2}{|c|}{$\begin{array}{l}\text { Coarse } \\
\text { mode }\end{array}$} \\
\hline & & & & & $\underset{(\mathrm{nm})}{\operatorname{AGMD}} \ddagger$ & $\%$ & $\underset{(\mathrm{nm})}{\operatorname{AGMD}}$ & $\%$ & $\underset{(\mathrm{nm})}{\operatorname{AGMD}}$ & $\%$ & $\underset{(\mathrm{nm})}{\operatorname{AGMD}}$ & $\%$ \\
\hline 10815 & $\begin{array}{l}120 \mathrm{~m} \text {, in front of a } \\
\text { water pond }\end{array}$ & 60 & 7 & $\begin{array}{l}4.98 \\
5.70\end{array}$ & $\begin{array}{l}0.89 \\
0.68\end{array}$ & $\begin{array}{l}2.6 \\
0.9\end{array}$ & $\begin{array}{l}62 \\
68\end{array}$ & $\begin{array}{l}96.5 \\
98.2\end{array}$ & $\begin{array}{c}784 \\
-\end{array}$ & 2.6 & $\begin{array}{l}4190 \\
1234\end{array}$ & $\begin{array}{l}0.09 \\
0.09\end{array}$ \\
\hline 20817 & & 65 & 7 & $\begin{array}{l}4.96 \\
6.15\end{array}$ & $\begin{array}{l}0.97 \\
0.69\end{array}$ & $\begin{array}{l}4.6 \\
1.3\end{array}$ & $\begin{array}{l}59 \\
65\end{array}$ & $\begin{array}{l}94.7 \\
98.1\end{array}$ & 865 & 0.9 & $\begin{array}{c}4817 \\
-\end{array}$ & $\begin{array}{l}0.7 \\
-\end{array}$ \\
\hline 30908 & & 70 & 8.9 & $\begin{array}{l}5.22 \\
6.37\end{array}$ & $\begin{array}{l}0.67 \\
0.56\end{array}$ & $\begin{array}{l}1.1 \\
1.2\end{array}$ & $\begin{array}{l}69 \\
74\end{array}$ & $\begin{array}{l}98.1 \\
99.0\end{array}$ & - & - & $\begin{array}{l}4987 \\
5224\end{array}$ & $\begin{array}{l}0.7 \\
0.6\end{array}$ \\
\hline 40910 & & 68 & 9.3 & $\begin{array}{l}5.33 \\
6.53\end{array}$ & $\begin{array}{l}1.29 \\
0.60\end{array}$ & $\begin{array}{l}3.1 \\
0.6\end{array}$ & $\begin{array}{l}82 \\
85\end{array}$ & $\begin{array}{l}96.3 \\
98.9\end{array}$ & - & - & $\begin{array}{l}3584 \\
2892\end{array}$ & $\begin{array}{l}0.6 \\
0.4\end{array}$ \\
\hline 50916 & $\begin{array}{l}90 \mathrm{~m} \text { level, bolt } \\
\text { storage area }\end{array}$ & 75 & 3.0 & $\begin{array}{l}1.41 \\
1.76\end{array}$ & 0.55 & 0.7 & $\begin{array}{l}63 \\
72\end{array}$ & $\begin{array}{l}98.2 \\
99.4\end{array}$ & - & - & $\begin{array}{l}3500 \\
4243\end{array}$ & $\begin{array}{l}1.2 \\
0.6\end{array}$ \\
\hline 61008 & & 55 & 2.5 & $\begin{array}{l}0.85 \\
1.02\end{array}$ & 4.34 & 23.9 & $\begin{array}{l}70 \\
75\end{array}$ & $\begin{array}{l}75.6 \\
89.8\end{array}$ & $\begin{array}{l}- \\
-\end{array}$ & $\begin{array}{l}- \\
-\end{array}$ & $\begin{array}{l}3427 \\
7893\end{array}$ & $\begin{array}{r}0.5 \\
10.2\end{array}$ \\
\hline 71009 & & 60 & 2.7 & $\begin{array}{l}0.72 \\
0.74\end{array}$ & $\begin{array}{l}1.72 \\
0.77\end{array}$ & $\begin{array}{c}13.4 \\
2 .\end{array}$ & $\begin{array}{l}52 \\
58\end{array}$ & $\begin{array}{l}85.2 \\
97.7\end{array}$ & - & - & $\begin{array}{l}3882 \\
3841\end{array}$ & $\begin{array}{l}1.3 \\
0.3\end{array}$ \\
\hline 81010 & & 65 & 3.7 & $\begin{array}{l}1.91 \\
1.79\end{array}$ & $\begin{array}{l}1.26 \\
0.7\end{array}$ & $\begin{array}{l}4.7 \\
1.0\end{array}$ & $\begin{array}{l}56 \\
57\end{array}$ & $\begin{array}{l}94.1 \\
98\end{array}$ & - & - & $\begin{array}{l}3430 \\
4740\end{array}$ & $\begin{array}{l}1.2 \\
1.0\end{array}$ \\
\hline 91014 & & 80 & 4.2 & $\begin{array}{l}2.29 \\
1.96\end{array}$ & $\begin{array}{l}0.78 \\
0.65\end{array}$ & $\begin{array}{l}2.6 \\
1.2\end{array}$ & $\begin{array}{l}52 \\
63\end{array}$ & $\begin{array}{l}96 \\
98.8\end{array}$ & - & - & $\begin{array}{c}2255 \\
-\end{array}$ & $\begin{array}{c}1.5 \\
-\end{array}$ \\
\hline 101015 & & 90 & 6.6 & $\begin{array}{l}0.76 \\
0.8\end{array}$ & $\begin{array}{l}1.29 \\
0.61\end{array}$ & $\begin{array}{l}4.5 \\
0.7\end{array}$ & $\begin{array}{l}63 \\
65\end{array}$ & $\begin{array}{l}95.4 \\
98.3\end{array}$ & - & - & $\overline{1990}$ & $\overline{-}$ \\
\hline
\end{tabular}


TABLE 2 (Cont'd)

\begin{tabular}{|c|c|c|c|c|c|c|c|c|c|c|c|c|}
\hline \multirow[b]{2}{*}{$\begin{array}{l}\text { Test } \\
\mathrm{D}, \mathrm{H}^{*}\end{array}$} & \multirow[b]{2}{*}{$\begin{array}{l}\text { Location \& event } \\
\text { (below surface level) }\end{array}$} & \multirow[b]{2}{*}{$\begin{array}{l}\mathrm{CNC}^{* *} \\
\left(\mathrm{~cm}^{-3}\right)\end{array}$} & \multirow[b]{2}{*}{$\underset{\left(\mathrm{kBq} \mathrm{m}^{-3}\right)}{\text { Radon }}$} & \multirow{2}{*}{$\begin{array}{c}{ }^{218} \mathrm{Pof}^{\dagger} \\
\left(\mathrm{Bqm}^{-3}\right) \\
\& \\
\mathrm{PAE}_{\left(\mu \mathrm{J} \mathrm{m}^{-3}\right)}\end{array}$} & \multicolumn{2}{|c|}{$\begin{array}{l}\text { Unattached } \\
\text { mode }\end{array}$} & \multicolumn{4}{|c|}{$\begin{array}{l}\text { Accumulation } \\
\text { size range }\end{array}$} & \multicolumn{2}{|c|}{$\begin{array}{l}\text { Coarse } \\
\text { mode }\end{array}$} \\
\hline & & & & & $\underset{(\mathrm{nm})}{\mathrm{AGMD}}$ & $\%$ & $\begin{array}{l}\text { AGMD } \\
(\mathrm{nm})\end{array}$ & $\%$ & $\underset{(\mathrm{nm})}{\operatorname{AGMD}}$ & $\%$ & $\underset{(\mathrm{nm})}{\operatorname{AGMD}}$ & $\%$ \\
\hline 111109 & & 200 & 2.1 & $\begin{array}{l}0.83 \\
0.75\end{array}$ & 3.2 & $\begin{array}{l}3.8 \\
-\end{array}$ & $\begin{array}{l}63 \\
66\end{array}$ & $\begin{array}{l}95 \\
98.7\end{array}$ & - & - & $\begin{array}{l}2498 \\
4223\end{array}$ & $\begin{array}{l}1.2 \\
1.3\end{array}$ \\
\hline 121110 & & 200 & 2.1 & $\begin{array}{l}0.83 \\
0.77\end{array}$ & $\begin{array}{l}2.71 \\
3.11\end{array}$ & $\begin{array}{r}18.0 \\
2.1\end{array}$ & $\begin{array}{l}72 \\
72\end{array}$ & $\begin{array}{l}81 \\
89\end{array}$ & - & - & $\begin{array}{l}3618 \\
8127\end{array}$ & $\begin{array}{l}1.0 \\
8.7\end{array}$ \\
\hline 131111 & & 120 & 2.1 & $\begin{array}{l}0.86 \\
0.79\end{array}$ & $\begin{array}{l}0.61 \\
0.61\end{array}$ & $\begin{array}{l}2.9 \\
0.3\end{array}$ & $\begin{array}{l}60 \\
62\end{array}$ & $\begin{array}{l}80 \\
78\end{array}$ & $\begin{array}{l}402 \\
350\end{array}$ & $\begin{array}{l}17.0 \\
15.8\end{array}$ & 2757 & $6 . \overline{0}$ \\
\hline 141114 & $\begin{array}{l}260 \mathrm{~m} \text { level, drilling } \\
\text { area, no men working }\end{array}$ & - & 12 & $\begin{array}{l}0.63 \\
0.43\end{array}$ & $\begin{array}{l}0.61 \\
0.61\end{array}$ & $\begin{array}{l}23.4 \\
13.0\end{array}$ & $\begin{array}{l}42 \\
44\end{array}$ & $\begin{array}{l}54.6 \\
66.8\end{array}$ & $\begin{array}{l}366 \\
351\end{array}$ & $\begin{array}{l}15.6 \\
15.7\end{array}$ & $\begin{array}{l}3592 \\
3300\end{array}$ & $\begin{array}{l}6.5 \\
4.5\end{array}$ \\
\hline 151116 & $\begin{array}{l}115 \mathrm{~m} \text { level, on the } \\
\text { stope, no activity }\end{array}$ & 100 & 11 & - & - & - & $\begin{array}{l}89 \\
88\end{array}$ & $\begin{array}{l}99.4 \\
100\end{array}$ & - & - & $\begin{array}{c}3699 \\
-\end{array}$ & $\begin{array}{r}0.6 \\
-\end{array}$ \\
\hline 161209 & $\begin{array}{l}115 \mathrm{~m} \text { level, on the } \\
\text { stope, men working }\end{array}$ & 200 & 12 & - & $\begin{array}{l}0.61 \\
0.63\end{array}$ & $\begin{array}{l}1.8 \\
0.8\end{array}$ & $\begin{array}{l}59 \\
80\end{array}$ & $\begin{array}{l}64.4 \\
67.1\end{array}$ & $\begin{array}{l}319 \\
375\end{array}$ & $\begin{array}{l}33.1 \\
31.2\end{array}$ & $\begin{array}{l}4958 \\
4747\end{array}$ & $\begin{array}{l}0.8 \\
0.7\end{array}$ \\
\hline 171211 & $\begin{array}{l}180 \mathrm{~m} \text { level, drilling } \\
\text { area, men working }\end{array}$ & 180 & 11.1 & $\begin{array}{l}8.12 \\
8.29\end{array}$ & $\begin{array}{l}0.61 \\
0.64\end{array}$ & $\begin{array}{l}1.1 \\
0.9\end{array}$ & $\begin{array}{l}47 \\
45\end{array}$ & $\begin{array}{l}65.1 \\
61\end{array}$ & $\begin{array}{l}317 \\
281\end{array}$ & $\begin{array}{l}33 \\
37.5\end{array}$ & $\begin{array}{l}3058 \\
3557\end{array}$ & $\begin{array}{l}0.9 \\
0.5\end{array}$ \\
\hline
\end{tabular}

* Sample number, the sampling date and time, respectively.

** Particle number concentration with nuclei counter (in 1000).

$\uparrow$ Upper number of each pair is ${ }^{218} \mathrm{Po}$ and the lower number is the PAE.

$¥$ Activity geometric mean diameter. 
TABLE 3

SIZE DISTRIBUTIONS OF LONG-LIVED NUCLIDES IN THE RABBIT LAKE URANIUM MINES, SASKATCHEWAN, CANADA, SAMPLED WITH THE MOUDI, NOVEMBER 1995

\begin{tabular}{|c|c|c|c|c|c|c|}
\hline & & \multicolumn{2}{|c|}{ Victoreen alpha monitors } & \multicolumn{2}{|c|}{ EML alpha scintillation systems } & \multirow{2}{*}{$\begin{array}{c}\frac{\text { A\&D analytical }}{\text { balance }} \\
\text { No. } 311,412\end{array}$} \\
\hline & & No. 311 & No. 412 & No. 311 & No. 412 & \\
\hline \multirow{2}{*}{$\begin{array}{l}\text { Stage } \\
\text { No. } \\
0\end{array}$} & \multirow{2}{*}{$\begin{array}{c}\begin{array}{c}\text { Cut-off } \\
\text { diameter } \\
(\mathrm{nm})\end{array} \\
15000\end{array}$} & \multicolumn{2}{|c|}{$\begin{array}{c}\text { Activity } \\
\left(\mathrm{mBq} \mathrm{m}^{-3}\right) \pm 1 \mathrm{SD}\end{array}$} & \multicolumn{2}{|c|}{$\begin{array}{c}\text { Activity } \\
\left(\mathrm{mBq} \mathrm{m}^{-3}\right) \pm 1 \mathrm{SD}\end{array}$} & $\begin{array}{c}\text { Mass } \\
(\mathrm{mg}) \pm 0.1\end{array}$ \\
\hline & & $0.54 \pm 0.07$ & $0.49 \pm 0.06$ & $0.48 \pm 0.03$ & $0.43 \pm 0.03$ & $0.01 \pm 0.1$ \\
\hline 1 & 10000 & $0.27 \pm 0.06$ & $0.31 \pm 0.06$ & $0.26 \pm 0.03$ & $0.25 \pm 0.02$ & $0.16 \pm 0.1$ \\
\hline 2 & 5600 & $0.49 \pm 0.06$ & $0.73 \pm 0.07$ & $0.41 \pm 0.03$ & $0.75 \pm 0.03$ & $0 \pm 0.05$ \\
\hline 3 & 3200 & $0.47 \pm 0.06$ & $0.88 \pm 0.08$ & $0.47 \pm 0.03$ & $1.04 \pm 0.01$ & $0.25 \pm 0$ \\
\hline 4 & 1800 & $0.31 \pm 0.06$ & $0.37 \pm 0.06$ & $0.28 \pm 0.03$ & $0.38 \pm 0.02$ & $0 \pm 0.15$ \\
\hline 5 & 1000 & $0.09 \pm 0.05$ & $0.16 \pm 0.05$ & $0.07 \pm 0.03$ & $0.17 \pm 0.02$ & $0.14 \pm 0.1$ \\
\hline 8 & 173 & $0.53 \pm 0.07$ & $0.33 \pm 0.06$ & $0.60 \pm 0.03$ & $0.37 \pm 0.02$ & $0.8 \pm 1.3$ \\
\hline B & 97 & $0.25 \pm 0.06$ & $0.06 \pm 0.05$ & $0.29 \pm 0.03$ & $0.07 \pm 0.01$ & $0.1 \pm 0$ \\
\hline BB & 45 & $0.19 \pm 0.05$ & $0.11 \pm 0.05$ & $0.17 \pm 0.03$ & $0.11 \pm 0.03$ & $0.37 \pm 0.5$ \\
\hline \multicolumn{2}{|c|}{ Backup filter } & $0.03 \pm 0.08$ & $0.08 \pm 0.08$ & $0.01 \pm 0.03$ & $0.08 \pm 0.06$ & $0.1 \pm 0.05$ \\
\hline
\end{tabular}



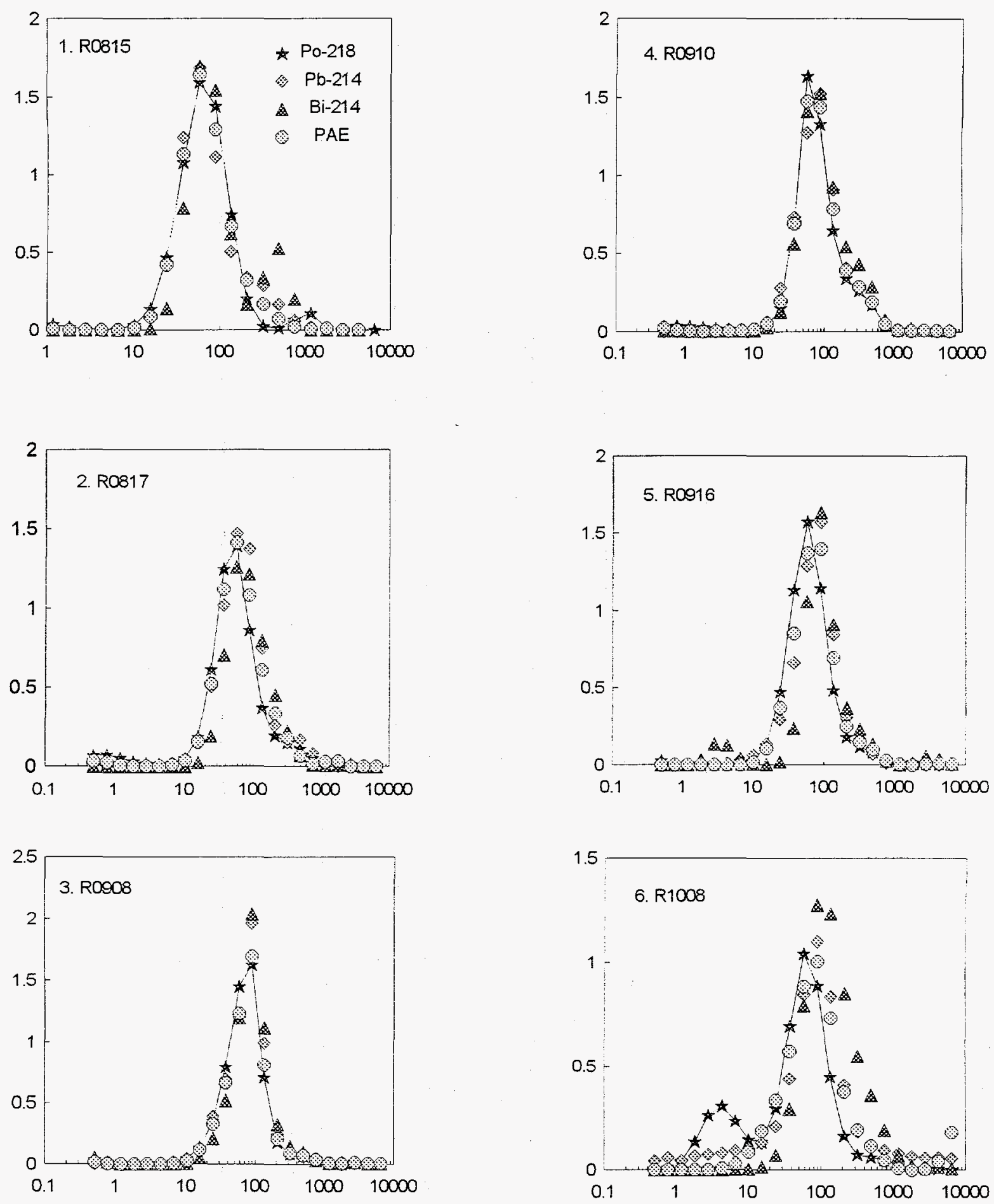

Figure $1 .{ }^{222} \mathrm{Rn}$ progeny size distributions, samples 1 to 6 . Absissa: particle diameter, $\mathrm{nm}$; ordinate: $\mathrm{dA} / \mathrm{A}$ dlog $\mathrm{D}, \mathrm{A}=$ alpha activity in $\mathrm{Bq} \mathrm{m}^{-3}$ for ${ }^{218} \mathrm{Po},{ }^{214} \mathrm{~Pb},{ }^{214} \mathrm{Bi}$, or in $\mathrm{nJ} \mathrm{m}{ }^{-3}$ for the $\mathrm{PAEC}, \mathrm{D}=$ diameter, nm. 

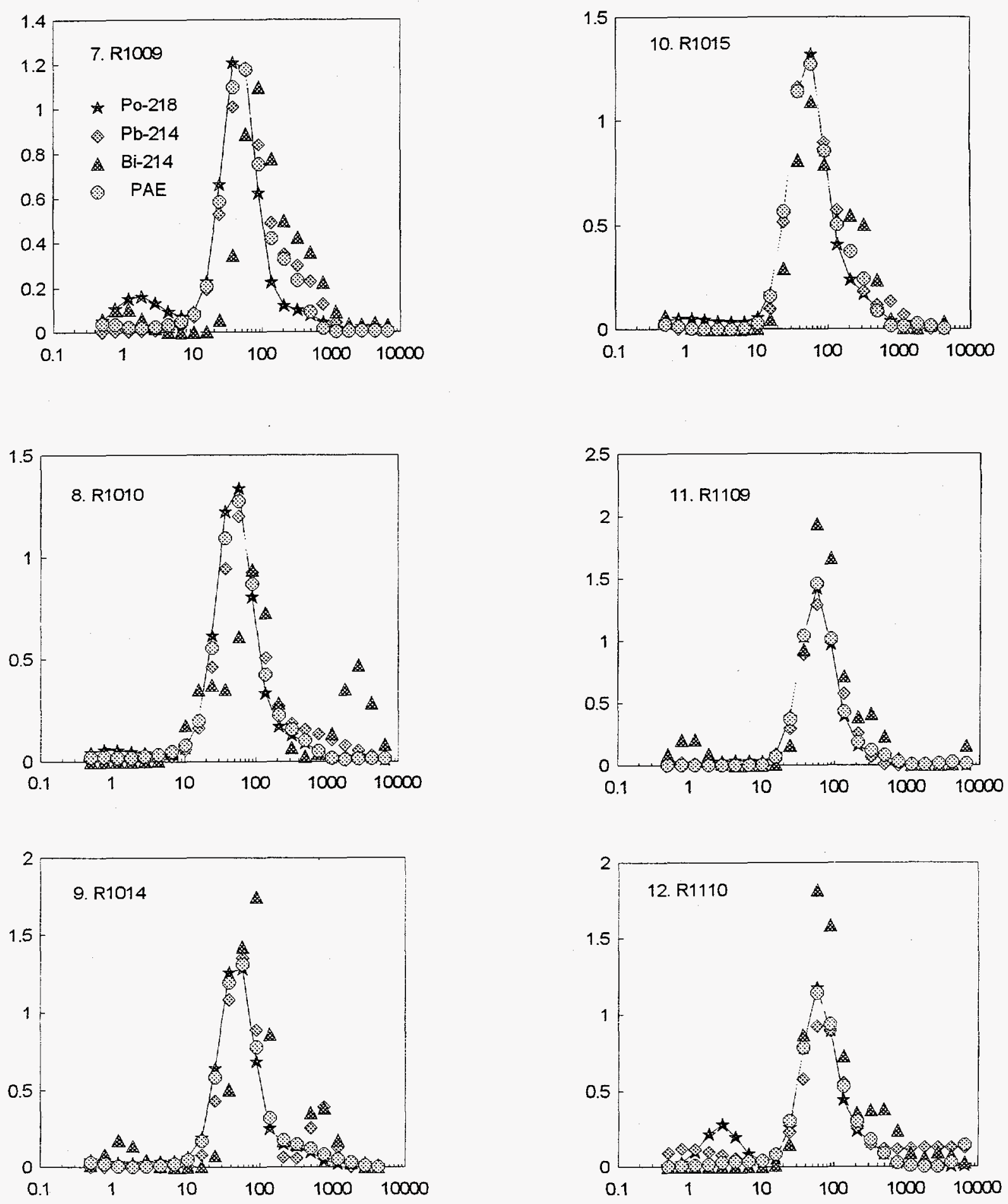

Figure 2. ${ }^{222} \mathrm{Rn}$ progeny size distributions, samples 7 to 12 . Absissa: particle diameter, nm; ordinate: $\mathrm{dA} / \mathrm{A}$ d $\log \mathrm{D}, \mathrm{A}=$ alpha activity in $\mathrm{Bq} \mathrm{m}^{-3}$ for ${ }^{218} \mathrm{Po},{ }^{214} \mathrm{~Pb}$ and ${ }^{214} \mathrm{Bi}$, or in $\mathrm{nJ} \mathrm{m}^{-3}$ for the $\mathrm{PAEC}, \mathrm{D}=$ diameter, $\mathrm{nm}$. 



Figure 3. ${ }^{222} \mathrm{Rn}$ progeny size distributions, samples 13 to 17 . Absissa: particle diameter, $\mathrm{nm}$; ordinate: $\mathrm{dA} / \mathrm{A}$ dlog $\mathrm{D}, \mathrm{A}=$ alpha activity in $\mathrm{Bq} \mathrm{m}{ }^{-3}$ for ${ }^{218} \mathrm{Po},{ }^{214} \mathrm{~Pb}$ and ${ }^{214} \mathrm{Bi}$, or in $\mathrm{nJ} \mathrm{m}^{-3}$ for the PAEC, $\mathrm{D}=$ diameter, $\mathrm{nm}$. 


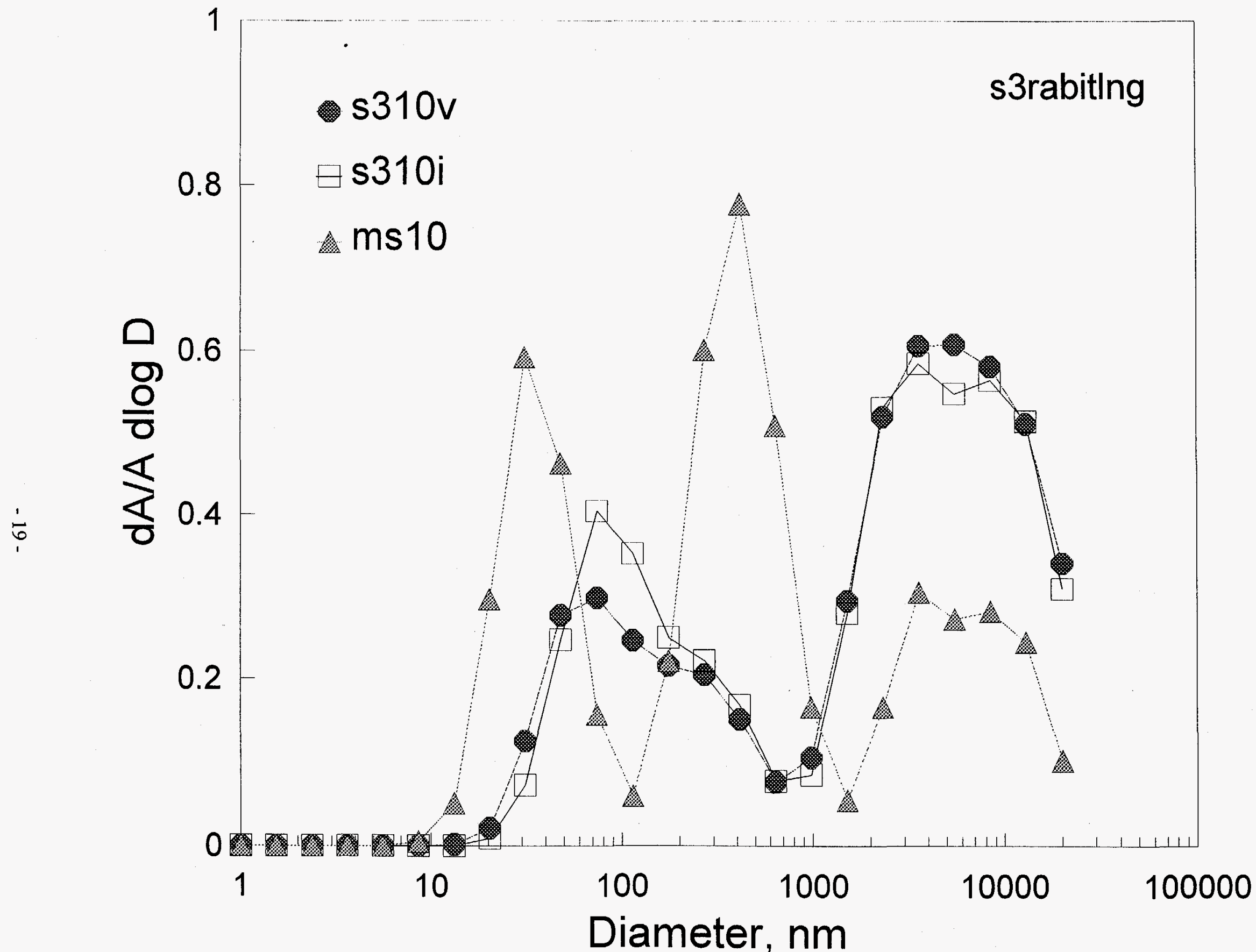

Figure 4. Sample 3, long-lived radionuclide size distributions: $\mathrm{ms} 10=$ mass-weighted; activity-weighted, $\mathrm{s} 310 \mathrm{v}=$ activity weighted measured with a Victoreen alpha spectrometer, and s310i = activity weighted, measured with an EML alpha counter. 


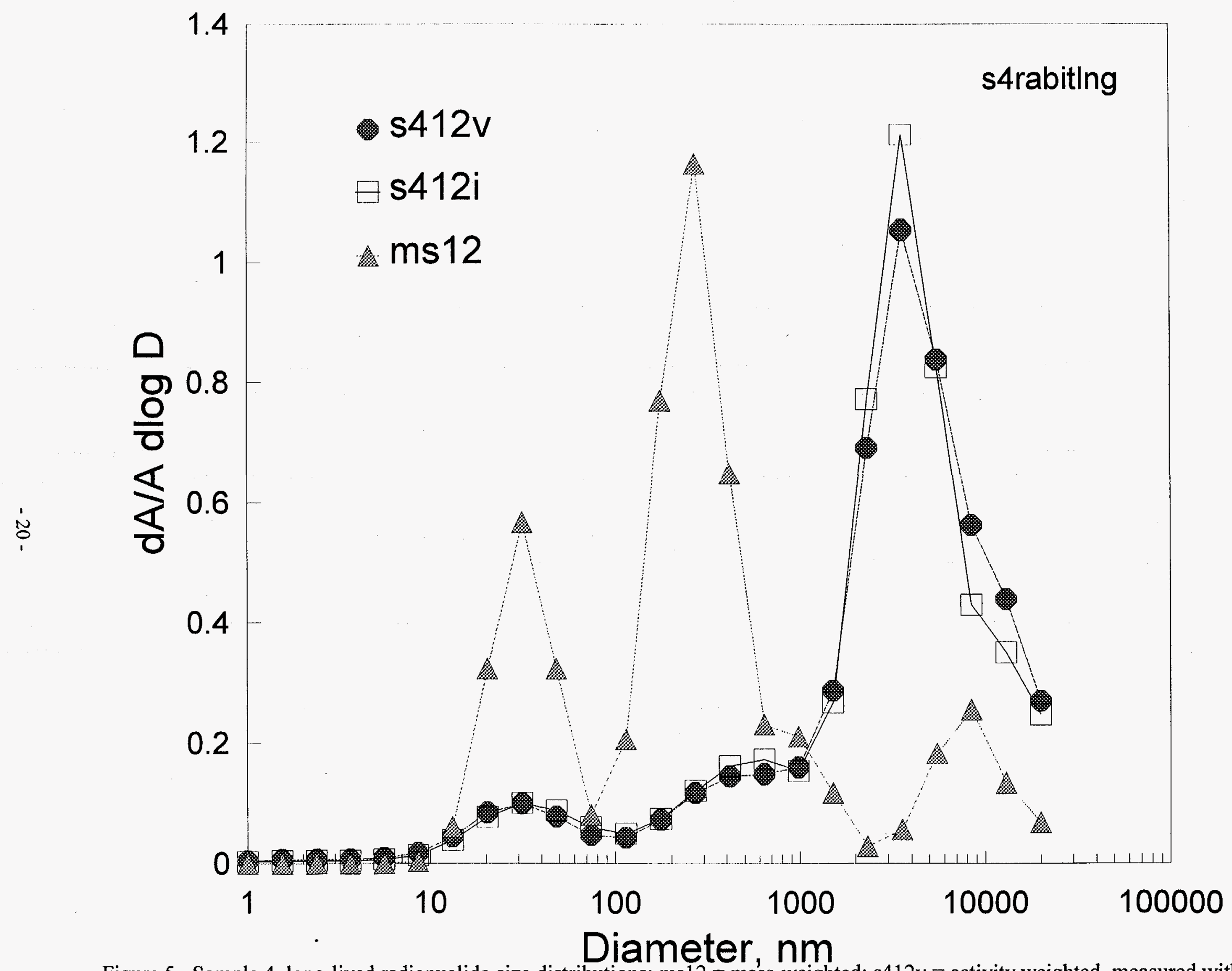

Figure 5. Sample 4, long-lived radionuclide size distributions: $\mathrm{ms} 12=$ mass-weighted; $\mathrm{s} 412 \mathrm{v}=$ activity weighted, measured with a Victoreen alpha spectrometer; $\mathrm{s} 412 \mathrm{i}=$ activity weighted, measured with an EML alpha counter. 

